九病虫研会報 $61: 57-61(2015)$

Kyushu Pl. Prot. Res. 61 : 57-61 (2015)

\title{
宮崎県で初確認されたモトジロアザミウマに対する薬剤の殺虫効果 およびスワルスキーカブリダニの捕食量
}

\author{
日高 春美 $^{\dagger}$ ・松浦明・森下勝 \\ （宮崎県総合農業試験場）
}

\begin{abstract}
Effect of several insecticides on Echinothrips americanus Morgan confirmed for the first time in Miyazaki Prefecture, and predation rate by Amblyseius swirskii. Harumi Hidaka $^{\dagger}$, Akira Matsuura and Masaru Morishita (Miyazaki Aguricultural Research Institute, Miyazaki, Miyazaki 880-0212, Japan)
\end{abstract}

2014年に宮崎県の施設ピーマンでモトジロアザミウマが初確認された。今後の再発生時の防除 対策に活かすため, 本種に対する各薬剂の殺虫効果とスワルスキーカブリダニの補食量を調査し た。成幼虫ともに補正死虫率が約 $90 \%$ 以上だった薬剤は, メソミル，ニテンピラム，スピネトラ ム, スピノサド, アバメクチン, エマメクチン安息香酸塩, クロルフェナピル, トルフェンピラ ドの 8 剂であった。また, 幼虫対象の薬剤ではスピロテトラマト, フルフェノクスロンおよびル フェヌロンの死虫率が $97.2 \sim 100 \%$ と高かった。ニテンピラム，スピノサド，エマメクチン安息香 酸塩の $\mathrm{LC}_{50}$ 值は, 各37.1ppm, $1.0 \mathrm{ppm}, 1.5 \mathrm{ppm}$ であり, ニテンピラムの $\mathrm{LC}_{50}$ 值が高いことから 今後の薬剤抵抗性の発達が懸念される。また，モトジロアザミウマ 1 齢幼虫は，スワルスキーカ ブリダニ雌成虫 1 頭に $2.8 \pm 1.0$ 頭 / 日捕食され，ミナミキイロアザミウマの $7.2 \pm 1.9$ 頭 / 日よりも 有意に少なかった。

Keywords : bioassay, insecticide resistance, sweet pepper, Thrips palmi Karny

緒

\section{言}

2014年 3 月に宮崎市の冬春ピーマン（品種：「宮崎 グリーン」）のビニルハウスにおいて，モトジロアザ ミウマEchinothrips americanus Morgan の発生と被 害が，宮崎県で初確認された。本種に寄生されたピー マンは，葉がかすり状になり，樹勢の低下が認められ た。しかし，同じくピーマンで食害が問題となるミナ ミキイロアザミウマThrips palmi Karny のように,

果実への被害は確認されなかった。

本種は，本邦において1999年に東京都小笠原村父島 のインゲンで初確認され，2002年に愛知県のシソで, その後西日本を中心に分布域が拡大しており，2015年 4 月現在，本県を含めて 7 都県で発生が確認されてい る。

本県で初確認されたピーマンハウスでは，伊藤・大

hidaka-harumi@pref.miyazaki.lg.jp
野（2003）により調査された薬剤感受性デー夕を参考 に, ピーマンのアザミウマ類に対して登録があるニテ ンピラム水溶剤およびルフェヌロン乳剤を用いて防除 を実施したことから，その後の発生は確認されていな い。また，伊藤・大野（2003）が寄主植物であると報 告しているピーマン, キュウリ, シソにおいて, 発生 地周辺の栽培ほ場を調査したが，発生が認められな かったため，本種の定着は防止できたと考えている。 しかしながら, 近年, アザミウマ類は各種殺虫剤に対 する感受性低下が問題となっており，アザミウマ種間， 同種内での個体群，さらには年次によって殺虫効果お よび薬剤感受性は変動するとされる（例えば西本ら， 2006 ; 岡崎ら, 2007 ; 柴尾- 田中, 2012 ; 西ら, 2013 ; 岡崎ら, 2014)。このため今回, 発生が確認さ れたモトジロアザミウマ個体群の殺虫剤感受性が，伊 藤・大野（2003）の報告と同様の傾向であるかは不明 であり，今後，本種の抵抗性発達により殺虫剤による 防除が困難になる可能性が考えられる。さらに本県の 
ピーマン栽培では, スワルスキーカブリダニ Amblyseius swirskii Athias-Henriotを中心とした防 除体系が広く普及している。このため, 本種に有効か つスワルスキーカブリダニに影響の少ない殺虫剤を選 定することは本種の再発生時に重要な防除資料となる。 そこで本試験では，ピーマンで登録のある薬剤を中心 に選定し，殺虫効果および感受性を検定した。また， 発生が確認されたピーマン八ウスでは，スワルスキー カブリダニが導入され，モトジロアザミウマの発生株 にもスワルスキーカブリダニの生息が確認された。し かし，本天敵がモトジロアザミウマをどの程度補食す るかは不明である。そのため, 本種に対してスワルス キーカブリダニによる防除の有効性を推察することを 目的に, 補食量も併せて調査したので報告する。

\section{材料および方法}

\section{1. 供試個体群}

モトジロアザミウマは2014年 3 月に宮崎市の冬春 ピーマンで採集した個体群を供試した。この個体群は, 室内に抒いてピーマンを慨として $22 \pm 1^{\circ} \mathrm{C}, 16 \mathrm{~L} 8 \mathrm{D} の$ 条件下で累代飼育し, 薬剤感受性試験では $3 \sim 5$ 世代 目の個体群を使用した。スワルスキーカブリダニの捕 食量試験に供試したミナミキイロアザミウマは，2008 年に宮崎県東諸県郡国富町で採集し，インゲンを飭と して $22 \pm 1^{\circ} \mathrm{C}, 16 \mathrm{~L} 8 \mathrm{D}$ の条件下で累代飼育した個体群 を供試した。供試幼虫は，ピーマン苗に雌成虫を接種 し， $25 \pm 1{ }^{\circ} \mathrm{C}, 16 \mathrm{~L} 8 \mathrm{D}$ の条件下で産卵させ，24時間後 に雌成虫を除去後， $25 \pm 1^{\circ} \mathrm{C} ， 16 \mathrm{~L} 8 \mathrm{D}$ の条件下に 7 日 間静置し孵化した個体を供試した。薬剂感受性試験で は 1 齢〜 2 齢幼虫, 捕食量試験では 1 齢幼虫を供試し た。

\section{2. 供試薬剤}

各供試薬剤と希釈倍数は第 1 表に示した。供試薬剤 は，ピーマンに農薬登録（2014年 4 月）のあるものを 中心に, 成虫は16薬郕, 幼虫は19薬片を選定し, 展着 剤としてトリトン X-100（ポリオキシエチレン（10） オクチルフェニルエーテル）を2,000倍となるよう添 加した水道水で常用濃度に希䣋して試験に用いた。対 照区においては，展着剤のみ試験区と同様に添加して 試験に用いた。

\section{3．成虫および幼虫に対する各薬剤の殺虫効果}

検定は岡崎ら（2014）の方法に準じ，ピーマン葉片 を10秒間薬液に浸漬する葉片浸漬法で行い，これを 3 枚のアクリル板によって挟む Munger cell 法 （Immaraju et al. 1992）を用いた。すなわち，順にア
クリル板 $(5 \times 7 \mathrm{~cm}$, 厚さ $2 \mathrm{~mm})$, 約 $1 \mathrm{ml}$ の水を滴下 したクッキングペーパー $(5 \times 7 \mathrm{~cm})$, 薬液に浸漬し 十分に風乾した直径 $5 \mathrm{~cm}$ のピーマン葉片，その上に穴 径 $4 \mathrm{~cm}$ のアクリル板（ $5 \times 7 \mathrm{~cm}$ ，厚さ $5 \mathrm{~mm} ）$ を重ねた。 その中に, 成虫 $11 \sim 19$ 頭, 幼虫 $8 \sim 16$ 頭を放飼し, そ の上にテトロンゴース（200メッシュ）を張った穴あ きアクリル板 $(5 \times 7 \mathrm{~cm}$, 厚さ $2 \mathrm{~mm}$, 穴径 $4 \mathrm{~cm})$ で覆 い，四方をクリップで固定した。これを $25 \pm 1{ }^{\circ} \mathrm{C}$, 16L8D の条件下に静置し, 成虫は48時間後, 幼虫は 72時間後に実体顕微鏡下で生死の判定を行った。試験 はいずれも 3 反復実施し，Abbott（1925）の補正式 により補正死虫率を算出した。

\section{4. 成虫に対する 3 薬剤の $L C_{50}$ 值}

薬剂感受性検定に用いた薬剂の中から, 宮崎県の ピーマン栽培で一般的に使用されているニテンピラム 水溶剂，スピノサド水和剂㧍よびエマメクチン安息香 酸塩乳剤の 3 薬剂について $\mathrm{LC}_{50}$ 值を調査した。試験は, 5 段階に希釈した薬液を用いて，常用濃度における感 受性検定と同様の方法で行った。48時間後の補正死虫 率からプロビット法により $\mathrm{LC}_{50}$ 值を算出した。試験 は 1 濃度あたり 3 反復実施し， 1 反復に成虫 $16 \sim 22$ 頭 を供試した。

\section{5. スワルスキーカブリダニによる捕食量}

モトジロアザミウマとミナミキイロアザミウマの 1 齢幼虫に対するスワルスキーカブリダニ雌成虫の 1 日 当たりの補食量を調查した。試験は柿元ら（2004）の 方法を一部改変して行った。 $2 \mathrm{~cm}$ 四方のピーマン葉片 にアザミウマの 1 齢幼虫を 20 頭とスワルスキーカブリ ダニ雌成虫 1 頭を接種し, これをガラス管（直径 $3 \mathrm{~cm}$, 高さ $3 \mathrm{~cm}$ ）にいれ，開口部をパラフィルムで覆った。 この飼育管には加湿による水滴の付着を防ぐため $2 \mathrm{~cm}$ 四方の滤紙を入れた。これを $25 \pm 1^{\circ} \mathrm{C} ， 16 \mathrm{~L} 8 \mathrm{D}$ の条件 下に静置し，24時間後に残存数を調查した。スワルス キーカブリダニの捕食によらない各アザミウマの死亡 数を考慮するため, スワルスキーカブリダニを導入し ない区を対照区として設け，試験区と対照区の差を推 定捕食量とした。各試験区 10 反復，刘照区 6 反復で実 施した。供試したスワルスキーカブリダニは，スワル スキー ${ }^{\circledR}$ (コパート社製) を用い，資材が到着した当 日に，実体顕微鏡下で本天敵が十分に活動しているの を確認後に供試した。

\section{結果}

\section{1．成虫および幼虫に対する各薬剤の殺虫効果}

試験結果を第 1 表に示した。カーバメート系のメソ 
第 1 表＼cjkstart各薬剤のモトジロアザミウマに対する殺虫効果

\begin{tabular}{|c|c|c|c|c|c|c|c|}
\hline \multirow{2}{*}{ 系 統 ${ }^{\text {a) }}$} & \multirow{2}{*}{ 供 試 薬 剂 } & \multirow{2}{*}{ 剂型 ${ }^{\mathrm{b})}$} & \multicolumn{2}{|c|}{ 総供試頭数 } & \multirow{2}{*}{$\begin{array}{c}\text { 希釈倍数 } \\
\text { (倍) }\end{array}$} & \multicolumn{2}{|c|}{ 補正死虫率 $(\%)^{\mathrm{c})}$} \\
\hline & & & 成虫 & 幼虫 & & 成虫 & 幼虫 \\
\hline カーバメート系 & メソミル & WP & 45 & 45 & 1,000 & 100 & 87.2 \\
\hline \multirow{2}{*}{ 有機リン系 } & ME P & $\mathrm{EC}$ & 47 & 45 & 1,000 & 0 & 89.8 \\
\hline & マラソン & $\mathrm{EC}$ & 48 & 45 & 2,000 & 8.4 & 100 \\
\hline \multirow{2}{*}{ ピレスロイド系 } & シペルメトリン & $\mathrm{EC}$ & 44 & 40 & 2,000 & 0 & 97.4 \\
\hline & アクリナトリン & WP & 43 & 45 & 1,000 & 18.3 & 84.6 \\
\hline \multirow{4}{*}{ ネオニコチノイド系 } & イミダクロプリド & WP & 45 & 43 & 2,000 & 82.0 & 100 \\
\hline & ジノテフラン & SP & 48 & 45 & 2,000 & 84.8 & 100 \\
\hline & ニテンピラム & SP & 47 & 41 & 1,000 & 100 & 100 \\
\hline & アセタミプリド & SP & 45 & 43 & 4,000 & 15.0 & 97.4 \\
\hline \multirow{2}{*}{ スピノシン系 } & スピネトラム & WP & 44 & 45 & 2,500 & 100 & 100 \\
\hline & スピノサド & WP & 47 & 38 & 5,000 & 100 & 100 \\
\hline \multirow{2}{*}{ アベルメクチン系 } & アバメクチン & $\mathrm{EC}$ & 46 & 41 & 500 & 100 & 100 \\
\hline & エマメクチン安息香酸塩 & $\mathrm{EC}$ & 44 & 38 & 2,000 & 100 & 100 \\
\hline クロルフェナピル & クロルフェナピル & $\mathrm{SC}$ & 52 & 45 & 2,000 & 100 & 100 \\
\hline METI 剂 & トルフェンピラド & $\mathrm{EC}$ & 46 & 44 & 1,000 & 91.9 & 100 \\
\hline 作用機構が未特定 & ピリダリル & $\mathrm{SC}$ & 41 & 36 & 1,000 & 0 & 60.0 \\
\hline $\begin{array}{l}\text { テトロン酸および } \\
\text { テトラミ酸誘導体 }\end{array}$ & スピロテトラマト & WP & - & 39 & 2,000 & - & 97.2 \\
\hline \multirow{2}{*}{ ベンゾイル尿素系 } & フルフェノクスロン & $\mathrm{EC}$ & - & 42 & 4,000 & - & 100 \\
\hline & ルフェヌロン & $\mathrm{EC}$ & - & 43 & 2,000 & - & 100 \\
\hline
\end{tabular}

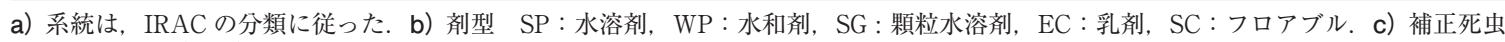
率は, Abbott（1925）の補正式により, 成虫で48時間後, 幼虫で72時間後の死虫率から算出した.

ミル水和剂の補正死虫率は，成虫幼虫ともに約 $90 \%$ 以 上と高かった。有機リン系の MEP 乳剂とマラソン乳 剂は成虫で各 $0 \%$ ，8.4\%，幼虫で各 $89.8 \% ， 100 \%$ と いずれも成虫に対する効果は低かったが，幼虫に対す る効果は高かった。ピレスロイド系のシペルメトリン 乳剂とアクリナトリン水和剂は, 成虫で各 $0 \%$, $18.3 \%$, 幼虫で各 $97.4 \%, 84.6 \%$ と有機リン系の 2 剂 と同様に幼虫の死虫率が高い傾向であった。ネオニコ チノイド系のアセタミプリド水溶剂は幼虫では $97.4 \%$ と効果は高かった。一方，成虫では $15.0 \%$ と他のネオ ニコチノイド剤が成幼虫含めて 82.0 1 $100 \%$ であった のと比較しても死虫率は低かった。スピノシン系のス ピネトラム水和剤, スピノサド水和剂, アベルメクチ ン系のアバメクチン乳剂, エマメクチン安息香酸塩乳 剂およびクロルフェナピルのクロルフェナピル水和剂 は，成虫および幼虫ともに $100 \%$ と高かった。METI 剤のトルフェンピラド乳剂は, 成虫で $91.9 \%$, 幼虫で $100 \%$ と死虫率はいずれも高かった。作用機構が未特 定であるピリダリル水和剂は成虫 $0 \%$, 幼虫 $60.0 \%$ と, 成虫に対する殺虫効果はなく，幼虫に対する効果もや
や低かった。幼虫に対してのみ検定を行ったテトロン 酸およびテトラミン酸誘導体のスピロテトラマト水和 剤, ベンゾイル尿素系のフルフェノクスロン乳剤とル フェヌロン乳剂は，いずれも $100 \%$ かほぼ近い值であ り，いずれも幼虫に対して高い効果が認められた。

\section{2. 成虫に対する3薬剤の $L C_{50}$ 值}

$\mathrm{LC}_{50}$ 值はニテンピラム水溶剤で $37.1 \mathrm{ppm}$, スピノサ ド水和剂で1.0ppm, エマメクチン安息香酸塩乳剤で $1.5 \mathrm{ppm}$ であり, ニテンピラム水溶剤の $\mathrm{LC}_{50}$ 值が 2 薬 剤の $\mathrm{LC}_{50}$ 值に比べて高く, ピーマンで農薬登録され ている常用濃度（50～100ppm）に近い結果であった (第 2 表)。

\section{3. スワルスキーカブリダニによる捕食量}

スワルスキーカブリダニ雌成虫の各アザミウマの 1 齢幼虫における 1 日当たりの捕食量は, モトジロアザ ミウマが平均 $2.8 \pm 1.0$ 頭, ミナミキイロアザミウマが 平均 $7.2 \pm 1.9$ 頭であった (第 3 表)。スワルスキーカブ リダニのモトジロアザミウマに対する捕食量は, ミナ ミキイロアザミウマに対する捕食量より有意に少な かった。 
第2表 モトジロアザミウマ成虫に対する 3 薬鼡の $\mathrm{LC}_{50}$ 值

\begin{tabular}{|c|c|c|c|c|}
\hline \multirow{2}{*}{ 系 統 } & \multirow{2}{*}{ 供 試 薬 剂 } & \multirow{2}{*}{ 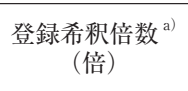 } & \multirow{2}{*}{$\begin{array}{c}\text { 常用濃度 b) } \\
\quad(\mathrm{ppm})\end{array}$} & \multirow[t]{2}{*}{$\frac{\mathrm{LC}_{50} \text { 值 }^{\mathrm{c})}}{\text { 浀度 }}$} \\
\hline & & & & \\
\hline ネオニコチノイド系 & ニテンピラム & $1,000 \sim 2,000$ & $50 \sim 100$ & 37.1 \\
\hline スピノシン系 & スピノサド & 5,000 & 50 & 1.0 \\
\hline アベルメクチン系 & エマメクチン安息香酸塩 & 2,000 & 5 & 1.5 \\
\hline
\end{tabular}

a) ピーマンに登録のある希釈倍数（2014年 4 月)。 b）登録希釈倍数より算出した常用濃度．c） $\mathrm{LC}_{50}$ 值は, Abbott（1925） の補正式により算出した補正死虫率からプロビット法により算出.

第3表 スワルスキーカブリダニによる各アザミウマ 1 齢幼虫の捕食量

\begin{tabular}{lccc}
\hline \multicolumn{1}{c}{ 供 試 虫 } & 反復数 & 捕 食 頭 数 & 有意差 $^{\mathrm{a})}$ \\
\hline モトジロアザミウマ & 10 & $2.8 \pm 1.0$ & \multirow{2}{*}{$*$} \\
ミナミキイロアザミウマ & 10 & $7.2 \pm 1.9$ & $*$ \\
\hline
\end{tabular}

a) 捕食頭数は, スワルスキーカブリダニを導入していない区の死亡数を引いた值（平 均值土標準偏差)。 b ) * は有意差あり $(U$-test $(P<0.05))$.

\section{考察}

今回，宮崎県で初確認されたモトジロアザミウマの 薬㘊感受性を調査した結果, 補正死虫率約 $90 \%$ 以上の 薬剤が, 成虫では 8 薬剤, 幼虫では17薬剤確認され, 有効な薬剤について明らかにできた。また，この中で スワルスキーカブリダニに影響の少ない薬郕は，アザ ミウマ成虫および幼虫に効果があるものではニテンピ ラム水溶剂とジノテフラン水溶剂, アザミウマ幼虫の みに効果があるものではフルフェノクスロン乳剤とル フェヌロン乳剤の計 4 剤であった（アリスタライフサ イエンス株式会社, 2015)。スワルスキーカブリダニ を用いた防除体系下で，本種の発生が確認された際に はこの 4 剂が有効であると思われる。

モトジロアザミウマの薬剤感受性は，国内では雌成 虫に対して，伊藤・大野（2003）と春山（2014）が報 告しているが，今回，本県で採集された個体群の死虫 率と伊藤・大野 (2003) の值を比較すると, マラソン 乳剂の死虫率が本県の方が低い以外は, ほほ同様の傾 向を示していた。一方，春山（2014）が栃木県内の八 イビスカスで採集した個体群は，今回の報告で成虫に 高い効果を示したメソミル水和剤，イミダクロプリド 水和剂, ジノテフラン水溶剂, ニテンピラム水溶剂, アバメクチン乳剤，エマメクチン安息香酸塩乳剤拈よ びトルフェンピラド乳剂の計 7 剂での殺虫効果が低く なっていた。このことからモトジロアザミウマは, 数 種の薬剤に対して感受性が低下していることが示唆さ れた。今回, 本県で使用頻度の高い 3 薬剤の $\mathrm{LC}_{50}$ 值 を調查したところ，そのうち常用濃度で効果の高かっ たニテンピラム水溶剤の $\mathrm{LC}_{50}$ 值が $37.1 \mathrm{ppm}$ であった。
この数值は, ピーマンで登録されている常用濃度（50 〜100ppm）に近い值であったことから，本県で発生 した個体群も，国内侵入当初より感受性が低下した個 体群であることが示唆された。今後は, 複数個体群で 検定を実施し，薬片感受性が個体群間において差異が あるか検討する必要がある。

本県のピーマン栽培において，スワルスキーカブリ ダニは一般的に広く導入されている。本天敵のモトジ ロアザミウマに対する補食量は，ミナミキイロアザミ ウマより有意に少なかった。モトジロアザミウマの総 産卵数は交尾䧳で $92.7 \pm 8.4$ 粒という報告があり（Li et al., 2012), ミナミキイロアザミウマ (寺本ら，1982) と同程度である。このことから，実際にほ場において 防除効果を検討する必要があるが，スワルスキーカブ リダニによるモトジロアザミウマの防除効果は低いと 推察される。

今後スワルスキーカブリダに対して影響の少ないニ テンピラム水溶剤やフルフェノクスロン乳剤などの殺 虫剂に対して, 感受性の低下した個体群が発生した場 合，スワルスキーカブリダニを利用したピーマンの防 除体系では大きな被害の発生が懸念される。そのため, 今後もモトジロアザミウマの発生には注意し, 再発生 時には今回明らかとなった有効な薬剤で速やかに防除 を行うとともに，薬剤感受性の調查や有効な天敵資材 等を明らかにすることが重要であると考える。

\section{引用 文 献}

Abbott, W. S. (1925) A method of computing the effectiveness of an insecticide. J. Econ. Entomol. 18 : 265-267. 
アリスタライフサイエンス株式会社（2015）商品同相 取扱説明資料 http://www.agrofrontier.com/ catalog/html/p_swalski.html（2015年 6 月17日ア クセス確認).

春山直人（2014）栃木県内で新たに発生したモトジロ アザミウマおよびチャノキイロアザミウマC 系統 に対する薬剤の殺虫効果. 関東東山病虫研会報 61 : $155-158$.

Immaraju, J. A., T. D. Paine, J. A. Bethke, K. L. Robb and J. P. Newman (1992) Western flower thrips (Thysanoptera: Thripidae) resistance to insecticides in coastal California greenhouse. J. Econ. Entomol. 85 : 9-14.

伊藤啓司・大野 徹 (2003) シソの新害虫モトジロア ザミウマ(仮称). 植物防疫 $57: 223-225$.

柿元一樹·井口拓士・井上栄明・櫛下町鉦敏 (2004) アザミウマ類に対するニセラーゴカブリダニの補食 能力. 九病虫研会報 $50: 82-87$.

Li, X., X. Zhang, H. Jiang and J. Feng (2012) Comparisons of developmental and reproductive biology between parthenogenetic and sexual Echinothrips americanus (Thysanoptera:

Thripidae). Environ. Entomol. 41 : 706-713.

西 優輔 · 佐野敏広 · 高馬浩寿 - 田中律子 - 長森茂之
（2013）岡山県の促成栽培ナスにおけるミナミキイ ロアザミウマ個体群に対する各種薬剤の殺虫効果.

九病虫研会報 $59: 81-85$.

西本周代・柿元一樹 ·井上栄明 $\cdot$ 柏尾具俊 (2006) 鹿 児島県内の花きほ場で発生する主要アザミウマ類 3 種に対する各種薬剤の殺虫効果. 九病虫研会報 52 : 49-53.

岡崎真一郎・奥田 充・櫻井民人 (2007) 大分県で採 集したミカンキイロアザミウマ個体群のエマメクチ ン安息香酸塩乳剂およびクロルフェナピル水和剤に 対する感受性低下. 九病虫研会報 $53: 66-77$.

岡崎真一郎 · 大坪亮介 · 加藤幸太郎 (2014) 大分県の 夏秋ピーマンにおけるミカンキイロアザミウマ個体 群の薬剂殺虫効果とスピノサド感受性低下個体群の 初確認. 九病虫研会報 $60: 79-83$.

柴尾 学・田中 寛 (2012) 大阪府のキュウリ・ナス 輪作施設におけるミナミキイロアザミウマ個体群の 薬剂殺虫効果. 関西病虫研報 $54: 67-69$.

寺本 敏・野中耕次・永井清文（1982）果菜類を加害 するアザミウマ類の生態と防除に関する研究 第 6 報 ミナミキイロアザミウマの産卵能力. 九病虫研 会報 $28: 128-129$.

(2015年 4 月 30 日受領, 7 月 13 日受理) 